\title{
統計モデルを用いた合意形成過程の定量的分析
}

Quantitative Analysis of Consensus Formation Process by Using Statistical Model

\section{橋本禅”佐藤洋平” 山路永司”“}

(*東京大学大学院農学生命科学研究科 **東京大学大学院新領域創成科学研究科)

\section{I 研究の背景と目的}

近年，地域計画策定過程への住民参加が重要視 されてきている。その背景として，地方行政にお ける行政計画の位圈つけの向上, 行政計画に内在 する久点の是正 "), 住民の日常的な要求の変化等 が挙げられる 2)。この傾向は今後，地方分権化の 波, 地域住民の直接行動力の向上, 地方行政職員 の政策立案・遂行能力の向上に支えられ，ますま す強まるものと考えられる。

この流れを受けて，都市計画・建策・屡村計画 分野では，住民参加による地域計画策定に関する 様々な研究が行われている。しかし, 住民参加に は一定の型がなく, 地域毎に計画対象, 参加内容 等が異なっているため,こうした変動性のある点 に着目した研究では，一般性のある研究成果をあ げることは困奞であると考えられる。事実，米野 らによる, 過去の参加研究代論文の整理の試みも あるが，参加研究全般についての理論的な考察ま では至っていない。

本研究の目的は，住民参加において一般に重要 とされる，“住民の合意形成過程”について理論的 な視点の導入を行うことである。一般に，計画策 定における住民間の合意形成においては，参加住 民の社会属性，参加住民が居住する地域の状態， 計画内容等様々な要因が絡み, 問題を襩雑化させ ている。本研究では，住民の意見変化を表す遷移 確率注2)導入することで, 合意形成過程の巨視的 かつ定量的な記述を行い，住民参加における合意 形成問題に統一的な視点の導入を試みた。

\section{II 研究の仮説}

計画策定過程における地域社会での合意形成は， 住民個人レベルの計画合意の総体といえる。つま り、合意形成の最小単位は個人の計画合意に関す る意思決定なのである。この個人の意思決定過程 を，他者との関倸でみると図1のようになる。

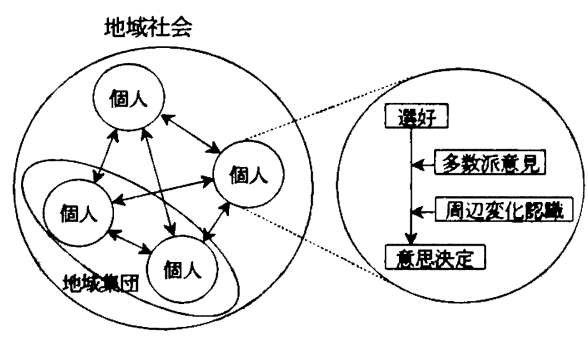

図 1 個人の意思决定過程

地域社会の成員は，計画案に対する独自の選好 を持ちつつも，参加過程において地域内における 多数派意見を知ることで同調行動を引き起こす。

ここで選好とは，他人の意見とは無関係に存在 する計画案に対しての個人的な選り好みで，個人 の生来の好みや個人的な慣習，あるいはある状㫛 に対する個人的な钼察や評価により形成されると 考えられる。

他者意見への同調は，個人が優勢な意見を採用 したがる意向によるもので，一度優勢な意見が出 るとその意向は更に強くなる。このような同調性 は，個人の本来の順応性あるいは個人が支配的な 意見に進んで賛成するように仕向けられる外的な 
圧力によるものと考えられる。一般に, 日常生活 の中で個人が同調行動をとる相手は，それ以前か ら関係のある人，以後の関係の持続する人である 場合が多い。

また計画による地域変化の可能性や，それに対 する危機意識は，それらが個人の生活に対して問 題をもたらすと判断されたときに，潜在的な価值 意識を表出させ選好に影響を与えるとともに，意 思決定に要する時間に対して触媒的な作用をもた らすと考えられる。

選好，同調及び周辺変化認識，これらすべての 要因の影響を受け，個人は計画合意に関寸る意思 決定を下すことになる。本研究における，合意形 成過程を記述寸る統計モデル(以下，合意形成モデ ル)はこれらの諸特性をその内部構造として有し ている。

\section{III 合意形成モデル}

合意形成モデルは，定常遷移確率をもつ Markov 過程这引を仮定した統計モデルで, 出生・ 死亡過程过)のアナロジーである。II で述べた様に， 本研究では個人の合意に関する意思決定は, 計画 案への『選好』と多数派意見への『同調性』によ り決まり, 決定に要する時間は意見変化の『柔軟 性』により影響を受けると考えている。

\section{1 モデルの仮定}

合意形成の状况を表すようなモデルの枠組みを 単純化するために，以下の 2 点を仮定する。 (1)地域社会には関連をもった $2 つ の$ 意見だけ，す なわち、“計画に合意”と“計画に非合意”だけが 存在する

(2)地域社会において各個人は，合意形成に関する 同一の遷移確率をもつ

これら 2 つ仮定の下に, 個人の意思決定に関 寸る遷移確率の定義を行う。

\section{2 モデルの棤造}

ここで,

$\mathrm{N}$ : 合意形成関与者数

$\mathrm{X}(\mathrm{t})$ ：時刻 $\mathrm{t}$ における計画合意者数 とする。
また，合意・非合意間の個人の僄移確率をそれ ぞれ次の様に定義する。

$$
\begin{aligned}
& \text { i) } i=0,1 \cdots, N-1 \text { において, } \\
& \operatorname{Pr}[X(t+h)=i+1 \mid X(t)=i]=\lambda_{1} \exp \left(\lambda_{2}+\lambda_{3} i\right) h+o(h) \\
& \text { ii) } i=1, \cdots, N \text { において, } \\
& \operatorname{Pr}[X(t+h)=i-1 \mid X(t)=i]=\lambda_{1} \exp \left(-\lambda_{2}-\lambda_{3} i\right) h+o(h) \\
& \text { iii) } j \notin\{i-1, i, i+1\} \text { において, } \\
& \operatorname{Pr}[X(t+h)=j \mid X(t)=i]=o(h) \\
& \text { iv) } i=0,1, \cdots, N \text { において, } \\
& \operatorname{Pr}[X(t+h)=i \mid X(t)=i]= \\
& 1-\lambda_{1}\left\{\exp \left(\lambda_{2}+\lambda_{3} i\right)+\exp \left(-\lambda_{2}-\lambda_{3} i\right)\right\} h+o(h) \\
& \text { ここで, } \lambda_{1}, \lambda_{2}, \lambda_{3} \text { は非負のパラメータで, }
\end{aligned}
$$

$\lambda_{2}$ : 選好パラメータ $\lambda_{2}$ は時刻けにおける合意者 数 $\mathrm{i}$ とは無関係に遷移確率值に影響を与え， $\lambda_{2}$ が 大きければ合意へと遷移する確率が増加する $\lambda_{3}$ : 同調性パラメータ $\lambda_{3}$ は時刻!における合意 者数iと共に透移確率值に影警を与え，iが大きい ほど遥移確率值は增加する

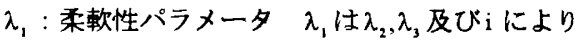
規定される値の前にかかることで遷移確率值に影 響を与え，合意形成の時間スケールを規定する と定義している。

$\mathrm{o}(\mathrm{h})$ は $\mathrm{h} \rightarrow 0$ のとき, $\mathrm{o}(\mathrm{h}) / \mathrm{h} \rightarrow 0$ を意味してい る。これより，i)〜iv) はそれぞれ，

$$
\begin{aligned}
& \text { i) } \lim _{h \rightarrow 0} \frac{\operatorname{Pr}[X(t+h)-X(t)=1 \mid X(t)=i]}{h}=\lambda_{1} \exp \left(\lambda_{2}+\lambda_{3} i\right) \\
& \text { ii) } \lim _{h \rightarrow 0} \frac{\operatorname{Pr}[X(t+h)-X(t)=-1 \mid X(t)=i]}{h}=\lambda_{1} \exp \left(-\lambda_{2}-\lambda_{3}, i\right) \\
& \text { iii) } \lim _{h \rightarrow 0} \frac{\operatorname{Pr}[|X(t+h)-X(t)| \geq 2 \mid X(t)=i]}{h}=0 \\
& \text { vi) } \lim _{h \rightarrow 0} \frac{\operatorname{Pr}[X(t+h)-X(t)=0 \mid X(t)=i]}{h} \\
& =1-\lambda_{1}\left\{\exp \left(\lambda_{2}+\lambda_{3} i\right)+\exp \left(-\lambda_{2}-\lambda_{3} i\right)\right\}
\end{aligned}
$$

と書け，i）は箪位時間あたりに合意者数が 1 增加 する確率, ii) は合意者数が 1 減少する確率, iii) は 合意者数が 2 以上変化(増加・减少)する確率, iv) は合意者数が不変の確率を表していることになる。

これより，生成行列Q を得る。この生成行列か ら Kolmogorov の微分方程式が導出できる。

Kolmogorov の微分方程式は,

$$
p_{i j}(t)=\operatorname{Pr}\left[X\left(t+t_{0}\right)=j \mid X\left(t_{0}\right)=i\right]
$$


で定義される確率 $p_{n}(t)$ を記述する微分方程式で，

$$
\mathbf{P}(\mathrm{t})=\left\|\mathrm{p}_{i j}(\mathrm{t})\right\|_{i, j=0}^{\mathrm{N}}, \mathbf{P}^{\prime}(\mathrm{t})=\left\|\frac{\mathrm{dp_{i }}(\mathrm{t})}{\mathrm{dt}}\right\|_{i, j=0}^{\mathrm{N}}
$$

を導入することで,

$$
\mathbf{P}^{\prime}(\mathrm{t})=\mathbf{P}(\mathrm{t}) \mathbf{Q}
$$

と書ける。ここで，P(t)， $\mathbf{P}^{\prime}(\mathrm{t})$ はそれぞれ要移確 率行列，遷移確率の時間微分を成分に持つ行列を 意味し, 遷移確率 $\mathbf{P}(\mathrm{t})$ の $(\mathrm{i}, \mathrm{j})$ 成分は初期時刻 $\mathrm{t}$ 。

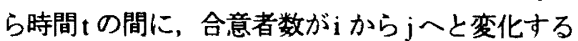
確率を表している。

Kolmogorov の微分方程式は初期条件 $\mathbf{P}(0)=\mathbf{I}$ の下で解け，その解は，

$$
\mathbf{P}(\mathrm{t})=\mathrm{e}^{\boldsymbol{Q}}=\mathbf{I}+\sum_{\mathrm{n}=1}^{\infty} \frac{\mathbf{Q}^{\mathrm{n}} \mathbf{t}^{\mathrm{n}}}{\mathrm{n} !}
$$

となる(但し、Iは単位行列)。

\section{3 モデルの適用}

合意形成モデルの適用は，静岡県掛川市平野地 区で住民主体により行われた集落土地利用計画策 定における計画合意者数の推移データを用いて行 った。計画策定は，1996 年 10 月から 1998 年 3 月までの 17 ヶ月にわたって行われここ間に合 意形成関与者 34 名全員が合意に達している(アン ケート票を用いた遡及調查による)。図 2 より計画 策定終了時期に合意者数犬゙多いことがわかる。

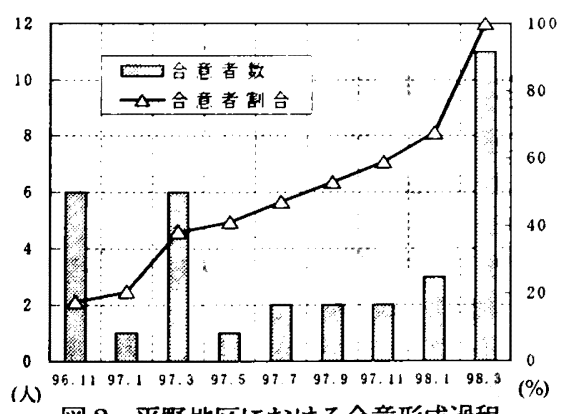

図 2 平野地区における合意形成過程

$$
\text { モデル中のパラメータ } \lambda_{1}, \lambda_{2}, \lambda_{3} \text { は, } \mathrm{N}=34 \text { とし, }
$$

表 1 のデータをもとに最尤推定でもとめた。

$$
\left(\lambda_{1}, \lambda_{2}, \lambda_{3}\right)=(0.056,2.091,0.070)
$$

このパラメータ值により, 生成行列 $\mathbf{Q} か ゙$ 定まり， 遷移確率行列 $\mathbf{P}(\mathrm{t})$ が算出可能となる。ここでは,

\begin{tabular}{|c|c|c|c|c|c|c|c|c|c|}
\hline$t$ & 1 & t & 3 & 4 & 5 & 6 & 7 & 8 & 9 \\
\hline 経過時間(ケ月) & 1 & 3 & 5 & 7 & 9 & 11 & 13 & 15 & 17 \\
\hline 萧者数の変 & 6 & 7 & 13 & 14 & 16 & 18 & 20 & 23 & 34 \\
\hline
\end{tabular}
初期合意者数を 0 人から 34 人まで, 起こり得る
合意者数を 0 人から 34 人まで想定しているので， 得られる遷移確率行列は 35 次の正方行列となる。

表 1 平野地区における合意者数の推移

また, 遡及調査で質問した時点分( 9 個)の遷移確 率行列が得られる。実際の合意者数の初期值は， 遡及調查により得られた値 6 に設定している。従 って, 遷移確率值は各時点における遷移確率行列 の第 7 行目に現れることになる。

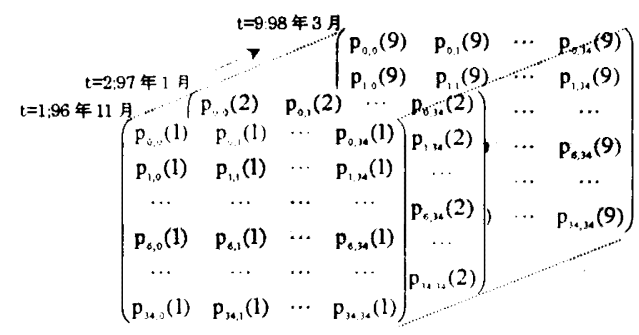

図 3 要移確率行列

求めた遷移確率行列の第 7 行目の時間変化を示 す。分布は合意形成開始から $3,7,11.15$ ヶ月 $(\mathrm{t}=2,4,6,8)$ の值である(図 4)。実際の合意者数を $\triangle$ で布置した。

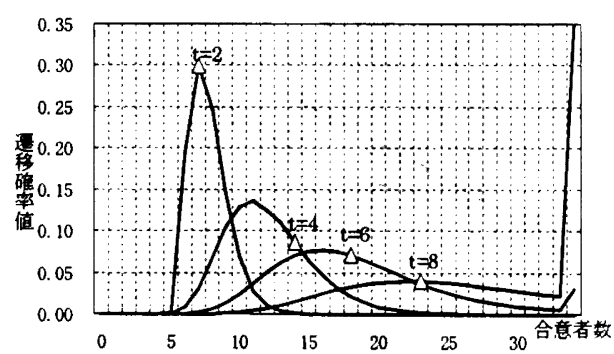

図4平野地区における遷移確率分布の推移

分布の峰に注目すると，時間と共に徐々に合意 一と分布が推移していることがわかる。また， で布置した実際の遷移数が, 峰の近傍に位置して いることから，本モデルがある程度の精度をもっ て実社会を記述していると考えることができる。 
しかし，この段階ではパラメータと僄移確率分 布との関係が十分に考察できないため，仮想社会 における合意形成過程を実験的に定めることで, パラメータ值と分布の関係の比較を試みた。

\section{IV 実験的考察}

\section{1 仮想社会における合意形成過程}

平野地区のデータをもとに，仮想社会における 合意形成過程を実䋡的に定め(表 2), 要移確率值を 求めることで，平野地区との比較を行った。

\section{表 2 合意者数の推移}

\begin{tabular}{|c|c|c|c|c|c|c|c|c|c|}
\hline$t$ & 1 & 2 & 3 & 4 & 5 & 6 & 7 & 8 & 9 \\
\hline 経週時问(ヶ月) & 1 & 3 & 5 & 7 & 9 & 11 & 13 & 15 & 17 \\
\hline 平野地区 & 6 & 7 & 13 & 14 & 16 & 18 & 20 & 23 & 34 \\
\hline A：個人主辣的 & 6 & 9 & 13 & 16 & 20 & 23 & 27 & 30 & 34 \\
\hline B：共同体的 & 6 & 7 & 9 & 11 & 14 & 18 & 22 & 27 & 34 \\
\hline
\end{tabular}

社会 $\mathrm{A}$ は計画への合意形成が，他者への同調な しに，計画への選好のみに依存している個人主義 的な社会を, 社会 Bは合意者数の増加と共に, 合 意への要移数が増加する共同体的社会を想定して いる。なお，平野地区との比較を容易にするため に，境界条件を同一にした(図 5)。

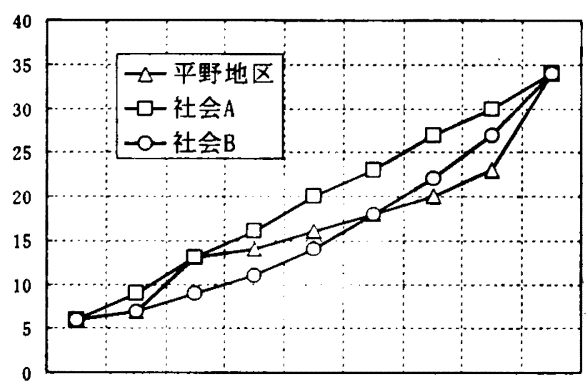

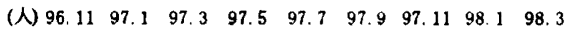

図 5 実呀的に定めた合意形成過程

パラメータ值は平野地区における場合と同様に 最尤推定で求めた。

社会 A : $\left(\lambda_{1}, \lambda_{2}, \lambda_{3}\right)=(0.022,4.386,0.000)$

社会 B : $\left(\lambda_{1}, \lambda_{2}, \lambda_{3}\right)=(0.017,3.742,0.052)$

個人主義的社会を想定した社会 A では，同調性 を表すパラメー夕值が0になっており，実際に合
意形成過程が計画への選好のみに依存していたこ とがわかる。また，共同体的社会を想定した社会 Bでは，同調性を表すパラメータ值が0でなく， 要移数がその時点における合意者数に传存してい ることがわかる。これより，モデルのパラメータ 值が，仮想社内の状態をある程度反映していると いうことができる。

分布中に, 実験的に与えた各時点の合意者数を， それぞれ口(社会 A)，O(社会 B)で示す(図 6)。但 し, 各分布は左から $\mathrm{t}=2,4,6,8$ 時点のものである。

両社会における要移確率分布の推移を比較する と, 個人主義的社会を想定した社会 $\mathrm{A}$ の僄移確率 分布の峰及び分散が、時間が経過してもそれほど 大きな変化を見せていないのに対し，共同体的社 会を想定した社会 $\mathrm{B}$ の要移確率分布の峰は時間変 化と共に減哀し，他方，分散は増大している事が わかる。

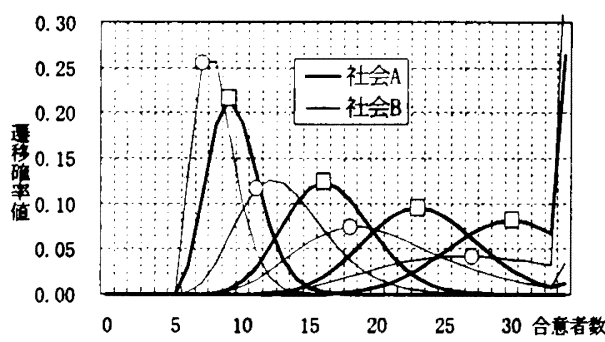

図 6 仮想社会における遷移確率分布の変化

つまり，共同体的社会 B では，時間が経過する ほど合意への僄移数が不確定になっているのであ る。これは，合意形成の長期的な予測が困難とな っていることを意味している。

以上を整理すると，モデルにおける各バラメー タの役割は次の様に整理できる。

$\lambda_{2}$ 選好パラメータが大きいほど，悉移確率分布 を前進させ，時間に依存せず，合意への安定的な 遷移をもたらす

$\lambda$ 、同調パラメータが大きいほど, 遷移確率分布 の峰が減衰し, 合意への僄移が不安定になる

\section{2 仮想社会と実社会の比較}

平野地区における悉移確率分布と, 仮想社会に おける迷移確率分布を比較すると, 平野地区にお 
ける分布は，共同体的社会を想定した社会 B の分 布に類似していることがわかる（図 7)。

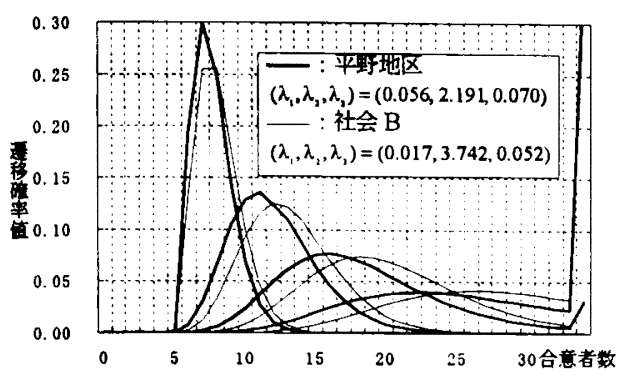

図 7 平野地区と社会 B の分布の比較

これより，平野地区における合意形成過程が共 同体的傾向にあると考えることができる。この結 果をより梁く考察すへく，次に平野地区社会にお ける合意形成関与者の合意理由に関寸る調查結果 の考察を行う。

\section{V 合意理由に関する調査結果}

平野地区での計画策定における合意形成関与者 34 名全員に，アンケート調查票を用いて計画策定 における合意理由について質問を行った(表 3)。回 答結果を図 8 に示す。

表3 アンケート調査票で用いた合意理由 (1) 計画に自分の考えが十分に反映されていたから

(2) 利益放多かったから

(3) 特に不利益を感じなかったから

(4) よく理解できていなかったが，裞得された

(5) 不利益があったが, 説得された

(6) みんなが同意していたから

(7) その他

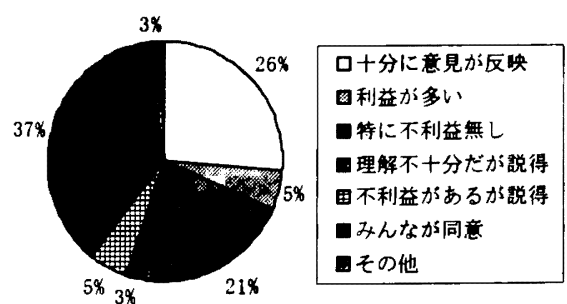

図 8 合意理由に関する調査結果
表 3 での合意理由(1)，(2)を『積極的合意』，(3) ら(6)までを『消極的合意』と考えると，前者が占 める割合が全体の $31 \%$ であるのに対し，後者のそ れは $66 \%$ と大きく，本計画が合意形成関与者の 100\%の同意を得てはいるものの, その内訳の大半 が消極的な理由によるものであることがかかる。

次に『消極的合意』内の項目を個別にみると，

「説得による合意」( 2 種類)は合わせても $8 \%$ と少 ないのに対し、「特に不利益無し」は $21 \%$ と比較 的高く、「みんなが同意していたから」に関しては $37 \%$ で，合意理由として最も多く選択されている のがわかる。このことから，合意に関する意思決 定において多数の合意形成関与者が，他者意見に 対して同調的な意思決定を下していると考えるこ とができる。

ここで得られた合意理由を，図 2 の合意形成過 程のグラフ上に皘み上げ表示すると, 更に興味深 い結果が得られた(図 9)。但し、久損值は分析から 除外した。

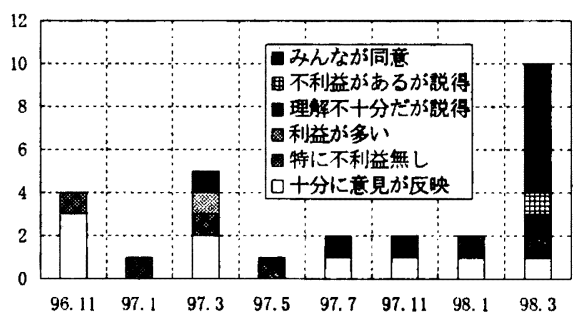

図 9 合意理由と合意時期

積極的理由による合意者の計画合意時期が計画 策定過程全般に渡るのに対し，消極的理由による 合意者の合意時期は計画策定終了時に集中してい る。ここから，消極的理由による合意者が，地区 内で合意に対する多数派意見が形成された後に， 提示された計画案に同調的に合意していた事を読 みとることができる。

平野地区における合意形成過程の同調的な傾向 は，III，IV の合意形成モデルによる分析からも示 されておりここでのアンケート調査に基づく合 意理由と合意時期との関係に関する考察が，その 裏付けをしているといえるであろう。 


\section{VI まとめ}

\section{1 結論}

本研究では，遷移確率を用いた統計モデルを桡 築し，合意形成過程の定量的な記述を試みた。実 社会一の適用及び，実験的考察から，本モデルが ある程度の精度をもって，実社会における合意形 成過程を記述しているといえる。これにより，計 画案に対する住民選好と地域社会の同調的傾向が， 合意形成過程に与える影望の定量的な関係が明ら かに出来た。得られた知見を以下に示す。

(1)選好パラメー夕に関する考察より，計画内容人 の選好が，合意形成において，合意への安定的な 僄移をもたら寸要因として作用していることが明 らかになった。従って，住民選好を十分に反映し た計画が立案されているかどうかが，合意形成を 促進寸る鍵になると考えられる。 (2)実社会と仮想社会における合意形成過程の比較， 及びアンケート調查に基づく合意理由に関する分 析から，同調パラメータの值が地域社会の社会棈 造を反映していることが明らかになった。同調パ ラメータが，遷移確蜜分布の分布の峰を時間と共 に減衰させる要因となっていることから，地域社 会の同調的な社会構造が，合意形成を不安定にさ せる要因であると考えることができる。地域社会 の同調的な社会䡔造は，多数派意見が形成される ことで住民合意を促進するとも考えられるが，同 時に反対意見が高まることで合意形成を阻害する 危険性も伴っている。このような社会では，計画 策定初期段階における意見形成が，その後の合意 形成に大きな影盟を与えると考えられる。

\section{2 今後の課題}

本研究においては現象を単純化するため，合意 形成に影響を与える要因を 3 パラメータで代表さ せたが，実際の合意形成過程は；様々な要因の影 響下にあると考えられる。
今後は複数地区での検証を通して各パラメータ をさらに検討し，パラメータに影響を与える要因 の詳細化を行う必要がある。これにより，より精 度の高いモテルを構築すると同時に，合意形成過 程の特性を評価できる標準指標の提案が可能とな ると考えられる。

[注]

注 1)参加研究とは文中で「絫加行為を対象として，特定の 点に着目し何らかの手法を用いて対象を理論化する こと」と定義されている。詳細は，Web Site， http://www.soc.titech.ac.jp/titsoc/harashinalab/fmeno/sanka/index.html を参照のこと。

注 2)䄐移確审を用いた意見形成モデルに関する詳細な記 述は，W.Weidlich ら す产照のこと。Weildlich らは 確事微分方程式を用いることで意見形成の理論的な 考察を行っているが，二の䅲の研究ではデー夕を収集 することが困難であり，モテルを実社会へ適用するに は至らないことが多い。本研究は Weildlich らにより 提示された意見形成に関する瑟移確率の基本型を発 展させ，出生・死亡過程を記述する Markov 過程に組 み込むことで，実社会の合意形成に䢔用したという点 にオリジナリティがある。

注 3)Markov 過程が定常㬊移確率を持つ時, $\mathrm{P}(\mathrm{s}, \mathrm{X} ; \mathrm{t}, \mathbf{A})=\operatorname{Pr}[\mathrm{X}(\mathrm{t}) \in \mathbf{A} \mid \mathrm{X}(\mathrm{s})=\mathrm{x}], \mathrm{t}>\mathrm{s}$ は， $x, A$ を固定すれば, $t-s$ の閔数になる。

注 4)出生・死亡過程住，生物の個体数の変化を礁案的に記 述するモテルで，ある条件下(十分な食物，無移住 etc …で，与えられた䂃問に一つの出生・死亡の起こる確 率はその時点での集団の大きさに比例しているという 仮定の下に符策されている。 Markov 過程及び，出生・ 死亡過程についての詳細な記述は S.Karlin”を参照の こと。

\section{文辣}

1)畠山武道(1994)：「住民参加と行政手統」，都市問題，第 85 巻，第 10 号 pp. 43-54 2)畠山武道(1997)：「地方自治体と住民参加」，都市問題， 第 88 巻，第 5 号 pp. 45-55

3)W.Weidlich，G.Hag 著寺本英，中禹久男，重定南奈子 (1990) : 『社会学の数学モデル』, 東海大学出版会 4)S.Karlin 著，佐藤健一，佐藤由身子盹(1974)：『確率過 程讙義』，産業図素

The purpose of this study is to build a statistical model, which describes consensus formation process, and to analyze its process quantitatively. The model built in this study is using Markovian process with continuous time and discrete set of events. The state of the process will be the number of people in the society convinced about plan. There are three parameters in this model namely preference, adaptation trend and flexibility. These parameters are considered as factors of individual decision-making process. Applying this model to the real society, we can estimate these three parameters. With the experimental consideration, it should be clear that this model could describe the real world. 